Selcuk Journal of Agriculture and Food Sciences

http://sjafs.selcuk.edu.tr/sjafs/index

Research Article
SJAFS

(2019) 33 (3), 198-203

e-ISSN: $2458-8377$

DOI:10.15316/SJAFS.2019.176

\title{
Determination of Population Development and Infestation Rate of The Beet Armyworm [Spodoptera exigua (Lepidoptera: Noctuidae)] in Sugarbeet Fields in Ilgin (Konya) District
}

\author{
Emine KAYA ${ }^{1, *}$, Levent $\ddot{N} \ddot{U}^{1}$ \\ ${ }^{1}$ Selçuk University, Faculty of Agriculture, Deparment of Plant Protection, Konya, Turkey
}

\begin{tabular}{l}
\hline ARTICLE INFO \\
\hline Article history: \\
Received date: 21.06 .2019 \\
Accepted date: 31.07 .2019 \\
\hline Edited by: \\
Murat KARACA; Selçuk University, \\
Turkey \\
Reviewed by: \\
Erdal SERTKAYA; Hatay Mustafa \\
Kemal University, Turkey \\
Halil KÜTÜK; Bolu Abant İzzet Baysal \\
University, Turkey \\
\hline Keywords: \\
Infestation rate, \\
Ilgin, \\
Pheromone trap, \\
Population, \\
Spodoptera exigua, \\
Sugarbeet
\end{tabular}

\section{Introduction}

Sugar beet (Beta vulgaris L.) is a two-year, summer industrial crop from the family of Chenopodiaceae. Sugar Beet is not only the raw material of industry, but also a fodder crop with its leaf, head and pulp which is very valuable food in livestock fattening. It is grown as a raw material of sugar in our country (Özer \& Ertunç 2005).

Sugar beets are produced in 55 countries around the world, Turkey ranks 5th with $6.2 \%$ market share. Sugar beet, which ranks second in terms of the added value it provides in industrial crops, is a rotation crop and has been cultivated every four years since 2001. Sugar beet production in 2017 was 21 million 149 thousand tons and $29 \%$ of this production was realized in Konya (Tosun, 2018).

Beet armyworm is within the order of Lepidoptera (Noctuidae). The species among pests especially from the order of Lepidoptera, due to the damage they have

\footnotetext{
* Corresponding author email: emine21012@ gmail.com
}

created in recent years has begun to attract attention. As a result of the study, it is determined that Şanliurfa is rich in the species of Noctuidae family and S. exigua, which is one of the important pests, has caused economic damages in the cotton areas of Şanlıurfa (Ünlü \& Kornoşor 2003).

Spodoptera exigua polyphag is a pest and its host range includes cotton, corn, sunflower, tobacco, vegetables; and chenopodium album, black nightshade, celosia argentea among weeds. It can also be pest in forest and fruit trees (Anonymous, 2008). There are a number of studies on S. exigua, which have been reported by various investigators (Hassanein et al., 1972; Aarvik, 1981; Stewart et al., 1996) that it causes significant damages to different host plants in various ecosystems including potatoes. For example, Kiray (1964) reported that this species caused damage not to be underestimated in many cultigens in our country, especially in industrial crops. Iyriboz (1971) and Sertkaya et al. (2004) reported that it is one of the most important pests of cotton fields in our country but it has also caused significant damage in potato areas in various parts of our country. Yildirım et al. (1998) reported 
that they cause significant damage in sugar beet fields in Erzurum and its surroundings.

Sugar beet is one of the leading products in Konya and its surroundings due to the fact that ecological conditions in Ilgin (Konya) district are suitable for sugar beet production and there is a sugar factory in the district. This issue has been studied because there has been no study on the development of beet armyworm populations in sugar beet areas in the Konya region.

\section{Materials and Methods}

\subsection{Materials}

The main material of the study is the sugar beets grown in the Ilgin district and the beet armyworm living on these plants. In the study, the sex pheromone traps (1.5 mg E.E-8.10-dodecadien-1-ol) have been used.

\subsection{Method}

\subsubsection{Determination of trial fields}

In the study, a total of nine sampling areas were chosen. There were chosen three fields for each region in the center of Ilgın, in Düger and Karaköy.

2.2.2 Determination of adult population development of Spodoptera exigua

This study was carried out in nine different fields for two years in 2017 and 2018 in order to determine Spodoptera exigua's adult population development in three sugar beet fields (three fields in one region, total nine fields) located in central, Düger and Karaköy districts of Ilgin district center of Konya province. In order to determine the adult population development of Spodoptera exigua, sexual attractive Delta type traps were set in the second week of May (15 May) in the first year of the study and in the last week of April (25 April) in the second year of the study. One trap was placed in each field in a way to represent the field and a $1.5 \mathrm{~m}$ high board was placed in the field. Trap controls were performed twice a week until the first adult was captured, and once a week after the first adult was captured, the number of captured moths was recorded. Pheromone capsules were replaced with new ones every six weeks. Adhesive trays under the trap were changed when necessary by considering the adhesive properties.

2.2.3 Determination of infestation rate of Spodoptera exigua in sugar beet

The determination of the infestation rate of beet armyworm in sugar beet was started from the moment when larvae and / or damage were observed in the plants in sugar beet fields. 25 plants were checked in all fields in the nine locations where the trials were carried out in such a way that will represent the field each week. When eggs, larva and / or larval damage were observed on the controlled plants, these plants were accepted as infested and the percentage of infestation of the fields was calculated.

\section{Results and Discussion}

As a result of the study conducted in order to determine the population development of the beet armyworm and the rate of infestation, it has been determined that the pest population is low in Ilgin and causes little damage.

\subsection{Determination of Adult Population Development of Spodoptera exigua}

Traps were set on May 15th in 2017 and in April 25 in 2018 to determine the population development of beet armyworm in Sugar Beets. It was determined that the moths were caught on May 17 in the traps which were set on May 15 in order to determine the population development of sugar beet armyworms. In 2018, it was determined that the adult was caught on 13 May.

The population development of Spodoptera exigua in the centrum in 2017 and 2018 is given in Figure 1.

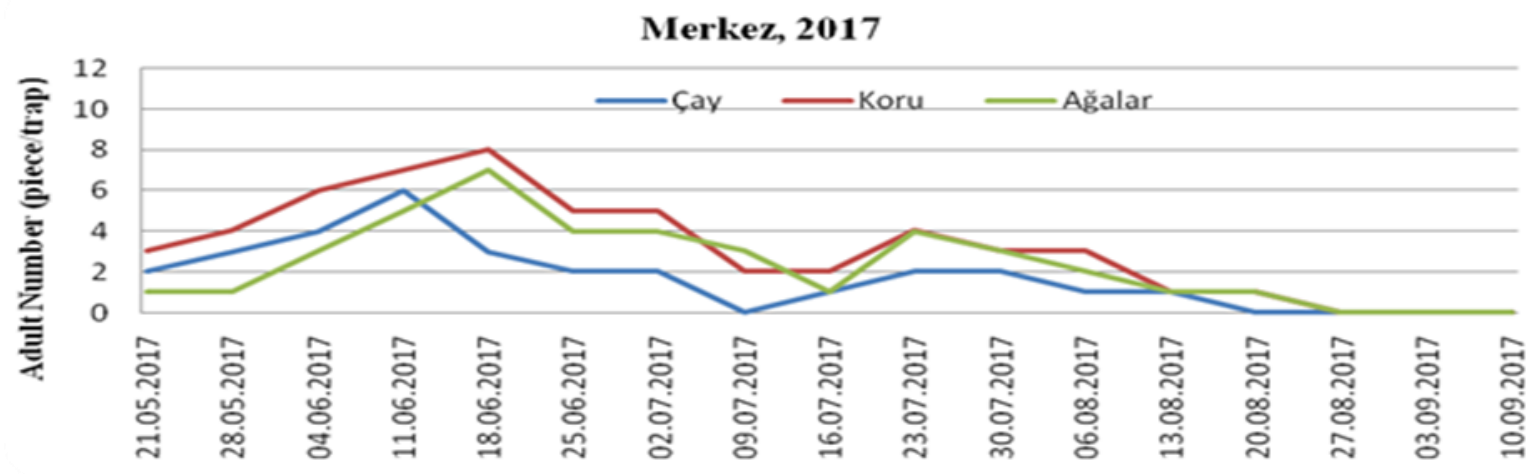




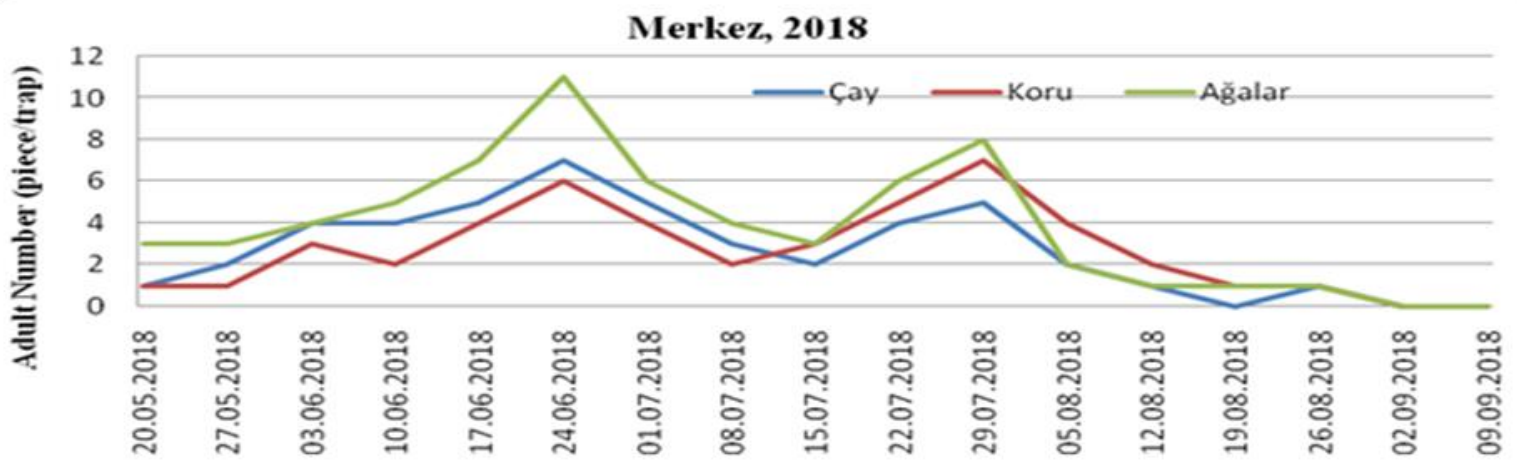

Figure 1

Population development of beet armyworm in sugar beet in the center of Ilgin in 2017-2018

In 2017, the beet armyworm adults in the sugar beet field in Çay, Koru and Agalar locations were first caught in pheromone traps on 17 May. The number of adults in the pheromone traps throughout the year was peaked twice in the second week of June and in the last week of July in each of the fields. Then, the population continued decreasingly. Spodoptera exigua was caught 8 times per week in Koru. The last date when adults were caught in the traps was determined as August 20.

In 2018, the beet armyworm adults in the sugar beet field locations were first caught in pheromone traps on
13 May in Agalar. The number of pest year was peaked twice on June 24 and on July 29 in each of the three fields. Then, the population continued decreasingly. The maximum number of Spodoptera exigua caught per week was 11 in Agalar location. The last date when adults were caught in the traps was determined as August 26 in Koru and Agalar (Figure 1).

Figure 2 shows the population development of Spodoptera exigua in 2017 and 2018 in Düger location.

Düger, 2017

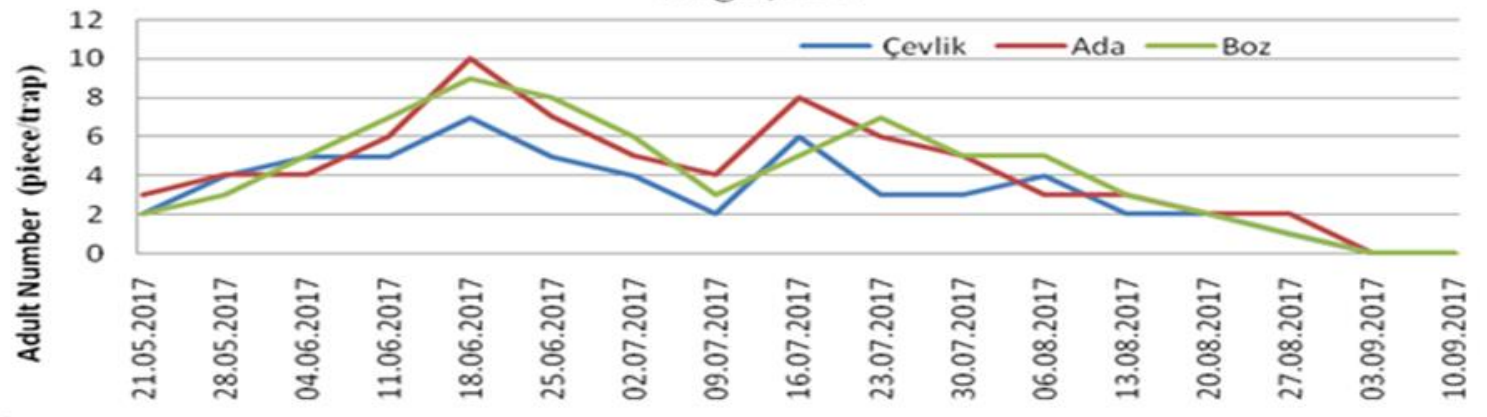

Düger, 2018

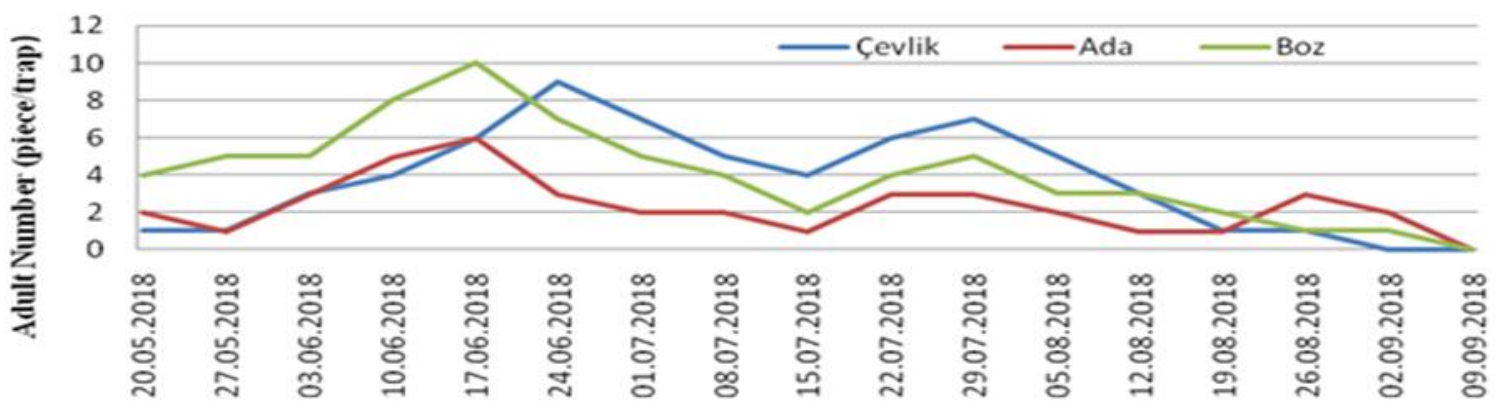

Figure 2

Population development of Spodoptera exigua in 2017 and 2018 in sugar beet in the location of Düger

In 2017, the beet armyworm adults in the sugar beet field locations were first caught in pheromone traps on May 17 in Düger. The number of pest year was peaked twice on June18 and in the second half of July in each of the three fields. Then, the population continued decreasingly. The maximum number of Spodoptera exigua caught per week was 10 in Ada location. The last date when adults were caught in the traps was determined as August 27.

In 2018, the beet armyworm adults in the sugar beet field locations were first caught in pheromone traps on May 16 in Ada location. The number of adults in the pheromone traps throughout the year was peaked twice in the second half of June and in the last week of July 
in each of the fields. Then, the population continued decreasingly. The maximum number of Spodoptera exigua caught per week was 10 in Boz location. The last date when adults were caught in the traps was determined as September 2 in Ada and Boz (Figure 2).
Figure 3 shows the population development of Spodoptera exigua in 2017 and 2018 in Karaköy location.

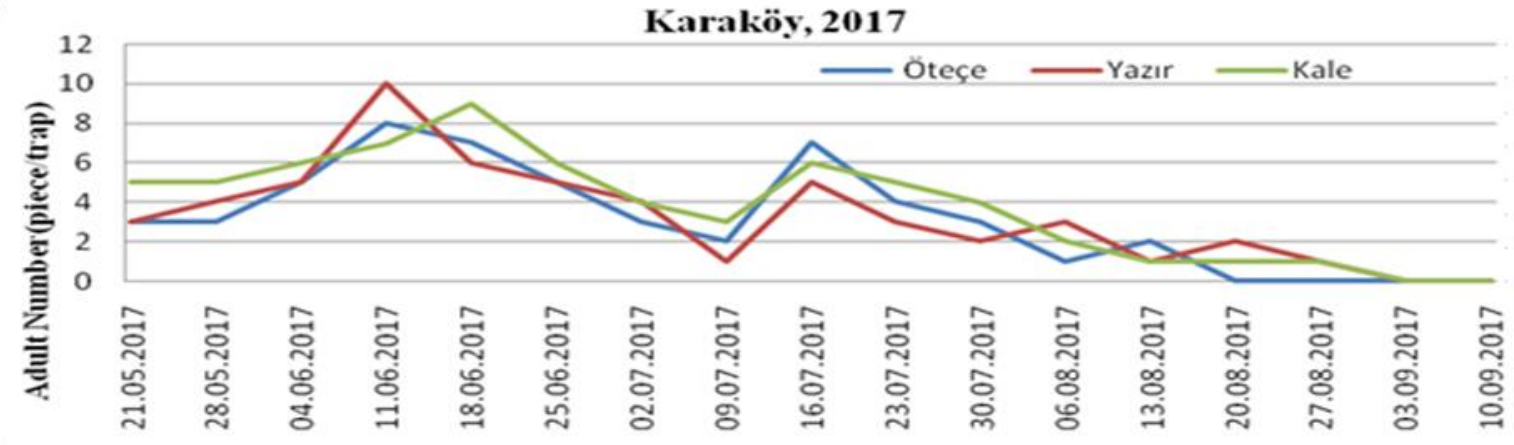

Karaköy, 2018

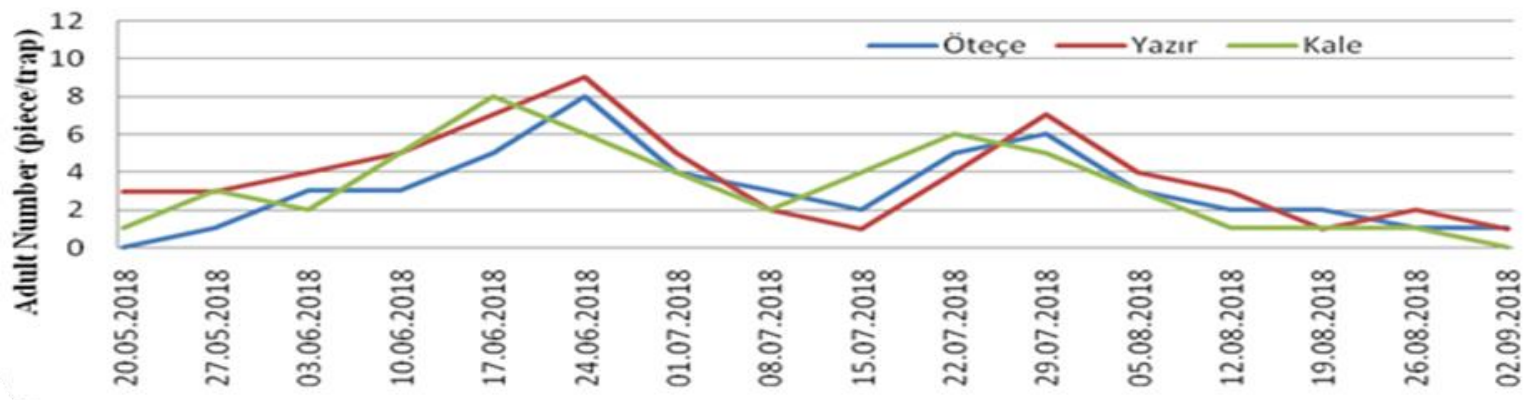

Figure 3

Population development of Spodoptera exigua in 2017 and 2018 in sugar beet in the location of Karaköy

In 2017, the beet armyworm adults in the sugar beet field locations were first caught in pheromone traps on May 17 in Karaköy. The number of pest year was peaked twice on June 11 and on July 16 in each of the three fields. Then, the population continued decreasingly. The maximum number of Spodoptera exigua caught per week was 10 in Yazır location. The last date when adults were caught in the traps was determined as August 27.

In 2018, the beet armyworm adults in the sugar beet field locations were first caught in pheromone traps on May 16 in Yazır location. The number of adults in the pheromone traps throughout the year was peaked twice in the second half of June and in the last week of July in each of the fields. Then, the population continued decreasingly. The maximum number of Spodoptera exigua caught per week was 9 in Yazır location. The last date when adults were caught in the traps was determined as September 2 in Öteçe and Yazır locations (Figure 3).

In the Centrum, Düger and Karaköy, where the study was conducted, it was determined that the first flight of the beet armyworm was seen in the first half of May in 2018 and it parallel the year 2017. The pests who peaked twice in each of the three sampling areas in 2017-2018 started to decrease in the first half of July. It then peaked second time, lower than the first. In this study, it was determined that the beet armyworm population in 2018 decreased in Düger and Karaköy compared to 2017 and increased in the Centrum. Due to the increase in sunflower cultivation areas, the other host of the pest in the centrum in 2018 , it is thought to be effective in increasing the population level in 2018 . In Düger and Karaköy, population levels decreased compared to the previous year. The reason for this is that 2018 may be rainy compared to 2017 .

In the study, it was determined that the first adults were caught by sexual attractive traps in the first half of May. Indeed, Atlihan et al. (2003) reported that the first adult flight of beet armyworm in Erciş and $\mathrm{Mu}-$ radiye was observed in June in a study conducted in potato fields, and similarly, a study conducted in a cotton field in Bismil District of Diyarbakır Province reported that $S$. exigua moths began to appear in sexual attractive traps on June 11 (Göven \& Gümüş, 1998). According to the technical instruction of agricultural control, it was reported that the mature adults spending the winter in the maize plant began to be seen towards the end of April (Anonim 2008). 
In 2017-2018, when the study was carried out, the time when the adult population was the most intense was determined as the middle of June and the end of July. It was reported that S.exigua, which caused significant damages in potato fields in Van province in 1998-1999, caused epidemic in 1998 and reached the highest population density in the season in late June and early July (Atlihan et al 2003). In a study conducted on soybean in 1981-1982 in Çukurova, while soybean plants had 3-4 leaves, S. exigua's population increased (Özdemir\& Uzunali 1981).

When it was decided to work in the fields in locations in 2017, the first year of the study, in interviews with producers, the producers stated that they did not encounter any significant damage of sugar beet armyworm. As a matter of fact, it was determined in our study, as well. In a study conducted in 1981-1982 in Çukurova, since there was no significant increase in

Table1

Spodoptera exigua infestation rate in Ilgin between years of 2017 and $2018(\%)$.

\begin{tabular}{llll|lll|lll}
\hline & \multicolumn{3}{c}{ Centrum $( \pm$ SE $)$} & \multicolumn{3}{c}{ Düger $( \pm$ SE $)$} \\
\hline Years & Çay & Koru & Ağalar & Çevlik & Ada & Boz & Öteçe & Yazır & Kale \\
\hline 2017 & $0.0 \pm 0.0$ & $0.0 \pm 0.0$ & $0.0 \pm 0.0$ & $0.0 \pm 0.0$ & $0.4 \pm 0.016$ & $0.0 \pm 0.0$ & $0.4 \pm 0.016$ & $0.4 \pm 0.016$ & $0.0 \pm 0.0$ \\
2018 & $0.0 \pm 0.0$ & $0.0 \pm 0.0$ & $0.4 \pm 0.016$ & $0.0 \pm 0.0$ & $0.0 \pm 0.0$ & $0.4 \pm 0.016$ & $0.4 \pm 0.016$ & $0.4 \pm 0.016$ & $0.0 \pm 0.0$ \\
\hline
\end{tabular}

In the Center, it was started from the period when the sugar beet had 8-10 leaves and during the weekly controls it was found that there was no infestation in the Çay and Koru locations in 2017-2018. While any infestation was not observed in Agalar in 2017, the average infestation rate in 2018 was $0.4 \%$.

In Düger, no infestation was seen in the sugar beet leaves in Çevlik location in 2017-2018. In Ada location, infestation was observed in the first week of $\mathrm{Au}-$ gust in 2017 and the average infestation was found to be $0.4 \%$. In 2018, no infestation was seen. In Boz location, no infestation was seen in 2017 and infestation rate was determined as $0.4 \%$ in 2018 .

In the weekly controls in Karaköy, Öteçe and Yazır locations, infestation rate was determined as $0.4 \%$ on 30.07.2017 and in the first week of August 2018. The average infestation was seen in 2017 in both locations and was found to be $0.4 \%$ in 2018 . In Kale location, no infestation was observed in both years of the study.

In 2017-2018 when the study was conducted, infestation was seen in the Center on 12.08.2018, it was seen in Düger in both years in the first week of August, it was seen in Karaköy at the end of July and in the first week of August, and the average infestation was determined as 0.4 . In a study carried out in maize fields in Çukurova, it was reported that the densest developmental stages of $S$. exigua larvae were the stages when they were with 2-4, 4-6 leaves (Güllü 2000). S. exigua larvae were found in the two-leaved stage of maize in Çanakkale and there was density in early seedling and middle rifling periods (Tiftikci\& Kornoşor 2015). Beet armyworm larvae were densely observed in the cotton field in Bismil District of Diyarbakır Province on June 18 and 22 (Göven \& Gümüş, 1998). In a study on pest pest population in soybean plants, it was seen as an insignificant pest in soybean, however, if we consider the fact that the increase in the population of S. exigua in Çukurova coincides with the emergence of the soybean and that there is increase in the population of cotton from time to time in the past years, it is possible that the there will be a significant pest in soybean plant (Turhan et al. 1983).In another study, S. exigua has been reported to be harmful, important lepidoptera species in maize-grown fields (Özdemir \& Uzunali 1981).

\subsection{Determination of pest infestation rate}

The amount of infestation seen in the gardens mainly shows the material loss caused by the beet armyworm for the producer. The infestation rate of $S$. exigua in 2017-2018, when the study was conducted, is given in Table 1. lepidoptera larvae in maize in Southeastern Anatolia, S.exigua larvae were found in the fields from July to September in 2003 and from the end of July to midSeptember in 2004. During the study, it was observed that $S$. exigua larvae caused damage to the second crop maize which was sown late (Gözüaçık \& Mart, 2009). In a study conducted on potato fields in Van province, S.exigua larvae were found on June 17 in Erciş and Muradiye (Atlihan et al 2003).

\section{Conclusions}

When the results of the population development of S.exigua conducted in the fields of Ilgin district center and locations in 2017-2018 are evaluated, the first adult flight was seen in the first half of May and the last adult flight was seen in the last week of August and the first week of September. The adult population peaked twice in June (11 units / week) and July (8 units / week) during the year. In the light of this information, it is concluded that beet armyworm can give two offspring because the first offspring are seen as from June. In this study, it was determined that adults of S.exigua remained active for approximately 4 months from midMay to the first week of September.

Considering the population and infestation rates of the pests, there was no significant increase of beet armyworms in the fields during the years of the research and it was found below the recommended economic thresholds and the sugar beet armyworm was considered as an insignificant pest for Ilgin district. In both years of the study, no spraying was recommended as there was not enough infestation to control with pesticide in Ilgın district. 
This pest is known as "Caradrina" among people because it causes serious damages in sugar beet by eating the leaves during the early seedling period. In the control, it is recommended to apply pesticide when there are 2 larvae/plants on average in 25 plants (Anonim, 2008). However, it is known that some pesticides are ineffective and pests gain resistance against some pesticides. For this reason, farmers are advised to use pesticides after consulting with experts. If spraying is performed correctly against first-stage generations, the reproduction and emergence of subsequent generations will be prevented. This is why first spraying is very important. It is necessary to follow these warnings to avoid damage to subsequent products. Since there was no significant increase in the population of pests in sugar beet plants in 2017-2018 when the research was carried out, it was not seen as an economic pest in sugar beet, but given the increase in the population of pests in sugar beet from time to time as in 2014 , it is likely that there is a significant probability of pests in sugar beet. It is therefore a pest that needs to be constantly monitored

\section{References}

Aarvik L (1981). The migrant moth Spodoptera exigua(Hubner) (Noctuidae: Lepidoptera) recordedin Norway. Fauna Norv., 28: 90-92.

Anonymous (2008). Zirai Mücadele Teknik Talimatlar1. Tar. Gida ve Hayvancılık, 1. Cilt: 116-119s

Atlıhan R, Yardım EN, Özgökçe MS, Kaydan MB (2003). Spodoptera exiqua (Hübner) (Noctuidae: Lepidoptera)'nın Van İli Patates Alanlarındaki Popülasyon Gelişmesi ve Doğal Düşmanları. Yüzüncü Y1l Üniversitesi, Ziraat Fakültesi, Tarım Bilimleri Dergisi. (J. Agric. Sci.) 13 (1):39-43.

Göven M, Gümüş S (1998). Diyarbakır (Bismil) İli Pamuk Alanlarında Zararlı Pamuk Çizgili Yaprakkurdu Spodoptera exigua (Hübn.) (Lep.: Noctuidae)'nın Doğal Düşmanları Üzerinde Bir Gözlem, Bitki Koruma Bülteni, 1998, 38 (3-4) :117120 ISSN 0406-3597.

Gözüaçık C, Mart C (2009). Güneydoğu Anadolu Bölgesi'nde Misırda zararlı bazı Lepidoptera larvalar1nın doğal parazitlenme oranlarının belirlenmesi, Bitki Koruma Bülteni 2009, 49(3): 107-116

Güllü M (2000). Çukurova'da mısırda zararlı Lepidoptera türlerinin farklı Misır çeşitlerindeki populasyon gelişmeleri üzerinde araştırmalar, Ç.Ü. FBE. Doktora Tezi, Adana, $198 \mathrm{~s}$.
Hassanein MH, Khalil FM, El-Naby AA (1972). Abundance and population density of three lepidopterous insects in the Upper-Egypt (Noctuidae: Lepidoptera ),Bull. Soc. Entomol. Egypte, 55: 79-83.

İyriboz NŞ (1971). Pamuk Zararlıları ve Hastalıkları, Ticaret Matbaacılık T.A.Ş., İzmir, 103s.

Kıray Y (1964). Çizgili Pamuk Yaprakkurdu (Karadrina) (Laphygma exigua Hbn.) Yaşayışı ve Mücadelesi, Tarım Bakanlığı Zir. Müc. Ens. Yay. No. 20, Adana, 27s

Özdemir N, Uzunali S (1981). Noctuid species causing damage to Maize in Turkey. EPPO Bull. 11 (2): 97-99.

Özer G, Ertunç F (2005). Amasya şeker fabrikası şeker pancarı ekim alanlarında Rhizomania hastalığının belirlenmesi. Tarım Bilimleri Dergisi, 11(3):339343.

Sertkaya E, Bayram A, Kornoşor S (2004). "Egg and Larval Parasitoids of the Beet Armyworm Spodoptera exigua on Maize in Turkey," Phytoparasitica, 32(3), 305-312.

Shahean AH (1980). Survey of pests attacking soybean plant in Egypt with some ecological notes.Rev.Appl.Entomol., 68 (2):10-13.

Stewart SD, MB. Layton, Jr. MR. Williams (1996). Occurrence and control of beet armyworm outbreaks in the cotton belt, Proceedings, Beltwide Cotton Conference, National Cotton Council of America, Memphis, TN. 846-848

Tiftikçi P, Kornoşor S (2015). Çanakkale'de Mısırda Zararlı Lepidoptera Türleri, Dağılımları ve Yayılışları Üzerinde Araştırmalar ÇOMÜ Zir. Fak. Derg. (COMU J. Agric. Fac.)2015: 3 (2): 107-118

Tosun F (2018). Şekerpancarı ürün raporu, Tarımsal Ekonomi ve Politika Geliştirme Enstitüsü, Yayın No: 309, 2018, Ankara

Turhan N, Tunç A, Belli A, Kişmir A, Kısakürek N (1983). Çukurova'da Soyada böcek ve akar faunasının tespiti üzerinde çalışmalar, Bitki Koruma Bülteni Cilt 23, No. 3, Adana

Ünlü L, Kornoşor S (2003). Şanlıurfa ilinde saptanan Noctuidae (Lepidoptera) familyası türleri ve morfolojik özellikleri, HR. Ü.Z.F. dergisi, 2003, 7(34):19-28

Yıldırım E, Aslan İ, Özbek H (1998). Oltu pancar bölge şefliğine bağlı şeker pancarı ekim alanlarındaki önemli zararlı böcek türleri ve mücadeleleri, Geçmişten Geleceğe Oltu ve Çevresi Sempozyumu, (13 Temmuz, 1998), Oltu-Erzurum, 576-585. 